\title{
Author Correction: Recent increases in tropical cyclone intensification rates
}

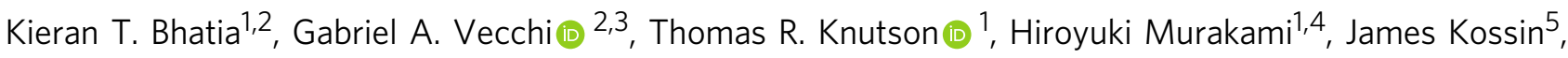 \\ Keith W. Dixon ${ }^{1} \&$ Carolyn E. Whitlock ${ }^{1,6}$
}

Correction to: Nature Communications https://doi.org/10.1038/s41467-019-08471-z, published online 7 February 2019.

The original version of this Article contained an error in the third sentence of the Acknowledgements, which incorrectly read 'Kieran Bhatia and Gabriel Vecchi were supported by National Science Foundation under Grant AGS-1262099 and in part by the Carbon Mitigation Initiative at Princeton University BP International 02085(7)'. The correct version states 'NSF EAR-1520683' in place of 'AGS-1262099'. Also, the original version of the Acknowledgements omitted the following from the end: 'Any opinions, findings, and conclusions or recommendations expressed in this material are those of the authors and do not necessarily reflect the views of the National Science Foundation'. This has been corrected in both the PDF and HTML versions of the Article.

Published online: 28 August 2019

\begin{abstract}
(c) Open Access This article is licensed under a Creative Commons Attribution 4.0 International License, which permits use, sharing, adaptation, distribution and reproduction in any medium or format, as long as you give appropriate credit to the original author(s) and the source, provide a link to the Creative Commons license, and indicate if changes were made. The images or other third party material in this article are included in the article's Creative Commons license, unless indicated otherwise in a credit line to the material. If material is not included in the article's Creative Commons license and your intended use is not permitted by statutory regulation or exceeds the permitted use, you will need to obtain permission directly from the copyright holder. To view a copy of this license, visit http://creativecommons.org/licenses/by/4.0/.
\end{abstract}

(C) The Author(s) 2019

\footnotetext{
${ }^{1}$ NOAA/Geophysical Fluid Dynamics Laboratory, Princeton, NJ 08540, USA. ${ }^{2}$ Geosciences Department, Princeton University, Princeton, NJ 08544, USA.

${ }^{3}$ Princeton Environmental Institute, Princeton University, Princeton, NJ 08544, USA. ${ }^{4}$ University Corporation for Atmospheric Research, Boulder, CO 80307 , USA. ${ }^{5}$ NOAA/National Centers for Environmental Information, Center for Weather and Climate, University of Wisconsin, Madison, WI 53706, USA.

${ }^{6}$ Engility Inc., Dover, NJ 07806, USA. Correspondence and requests for materials should be addressed to K.T.B. (email: kbhatia@princeton.edu)
} 